\title{
Perceived Benefits and Attitudes of Student Teachers to Web-Quest as a Motivating, Creative and Inquiry-Based Learning Tool in Education
}

\author{
Samuel Ayobami Aina ${ }^{1} \&$ Alaba Olaniyi Sofowora ${ }^{1}$ \\ ${ }^{1}$ Department of Educational Technology, Faculty of Education, Obafemi Awolowo University, Ile-Ife, Osun \\ State, Nigeria \\ Correspondence: Alaba Olaniyi Sofowora, Department of Educational Technology, Faculty of Education, \\ Obafemi Awolowo University, Ile-Ife, Osun State, Nigeria. E-mail: oasofowora@yahoo.com; \\ oasofowora@oauife.edu.ng
}

Received: July 18, 2013 Accepted: August 13, 2013 Online Published: September 22, 2013

doi:10.5539/hes.v3n5p29 URL: http://dx.doi.org/10.5539/hes.v3n5p29

\begin{abstract}
This study discussed how the Department of Teacher Education, University of Ibadan utilized Web-Quest as a motivating and creative tool to teach a compulsory and large pre-service teachers' Course (TEE 304) The study also investigated the attitude and perception of pre-service teachers to the use of Web-Quest. The results showed that the sample perceived Web-Quest as a useful creative, motivating pedagogical tool for learning. Student teachers perceived Web-Quest as interesting and highly beneficial to their learning. Gender was also a factor in the utilization of Web-Quest. Furthermore, students' age and gender had positive influence on their attitude to Web-Quest. The student teachers saw Web-Quest as an Inquiry-based pedagogical tool and learning strategy that enhanced team spirit, high level thinking, collaboration and that it saved costs and time.
\end{abstract}

Keywords: Web-Quest, collaboration, pedagogical tool, perception, disposition and quality education

\section{Introduction}

\subsection{Introduction to the Problem}

Nigeria is one of the African largest $\left(923,768 \mathrm{~km}^{2}\right)$ countries and the most populous countries with an estimated population of 155,215,573 million as at 2009. Apart, it is one of the richest African counties. However, one of the major challenges militating against its growth and development is the challenge of providing quality education to its qualified citizenry. Education today, has taken a new dimension because of globalization and the newly emerging technologies that has affected the demand and the way we do things. In the contemporary society, predictions about life and work for the coming decades are supposed to be made as a team through universal agreement and collaboration. Individuals are expected to move through several careers in the course of a lifetime. However, in Nigeria or Africa, the issues facing citizens are becoming more and more complex leading to societal problems that have deviled solutions. Nigerian Government have tried all possible best to provide solution to the menace and the bad image caused by one of the intractable impact of the social problem known as "BOKO HARAM" Which means objection to western education and civilization. The group is geographically situated in the Northern part of the country and has made a negative and destructive impact on the image / development of Nigeria. One of the remote causes of these sects is that they were not exposed to education and lacked the pre-requisite skills for gainful employment. As a result of which they resulted in act of terrorism. The situation might have been different if these groups are educated, gainfully employed and have committed themselves to a lifelong process of learning. Coincidentally, the past government did not make any provision for these would be tomorrow's citizens and leaders instead they have been turned into terrorists due to complete neglect and lack of qualitative education.

\subsection{The Importance of Education in Resolving the Challenges}

It is the realization of the importance of education as an important agent of development and globalization that made UNESCO and other Non Governmental Organizations like The Association for the Advancement Computing in Education (AACE) and Nigeria Association for Educational Media and Technology (NAEMT) show concern for the provision of quality education. It is the belief that provision of quality education and appropriate skills will enhance empowerment. Hence, the United Nation declaration: Education for All 
(UNESCO, 2000) and the Millennium Development Goals (MDGs). Apart from the above, the United Nations in the year 2005, declared 2005 to 2014 as the "Decade of Education for Sustainable Development" (ESD). According to the MDGs, it is compulsory for every member state to attain the following goals:

- ensure that all children particularly girls and children from the educationally disadvantaged areas are provided with quality primary education,

- make sure that the learning needs of all the young people and adults are met and in- line with MDGs,

- eradicate extreme poverty and hunger.

In view of the above, there is a need to employ creative, motivating and helpful techniques of teaching and learning in our classrooms that can help build a solid foundation that prepares our youths for the future and prevent them from being an instrument of destruction in the hands of the devil. It is a general axiom that an idle hand is the devil's workshop; to prevent this from happening, it is imperative that Nigeria should take the provision of good quality education for its citizens more seriously.

\subsection{Impact of International Organization in Resolving These Problems}

To achieve the MDGs, The Association for the Advancement of Computing in Education (AACE) a Unique International Organization having one of the objectives as ensuring the integration of emerging technology in improving the quality of education at all levels, came up with the New Year 2013 Conference focusing on multi-disciplinary approach for discussion and exchange of information on research, development, and applications in all topics related to multimedia, hypermedia and telecommunications/distance education. It also seeks to encourage the integration of ICT in K-12 and teaching of Science and Technology (National Research Council, 2001). This year's conference was designed for educational media specialists and teachers who were having interest in improving their teaching using modern technology. A Forum for Teachers and School Leaders, K-12 and other professionals in the educational sectors were also not left out, considering the importance of technology in ensuring qualitative education, AACE tagged the 2013 Conference: World Conference on Educational Media and Technology. The Association has for the past 25 years contributed immensely to the enhancement and development of education in the whole world. In addition, NAEMT in 2013 proposed a conference which was tagged: Educational Technology for Effective Service Delivery in Education, Training and Research. As a way to achieve the MDGs, NAEMT a Unique International Organization this year 2013, set out to help disseminate information about the potentials of Educational Technology in ensuring effective service delivery in the instructional process at all levels of education; service delivery in open and distance education ,training in business and industry; research and development etc. The impact of the Association is felt more in Africa especially in the area of providing the pre-requisite skills for university lecturers in the area of re-conceptualizing the curriculum, teaching improvement and provision of quality education to a large students using the newly emerging technologies. The Forum has also added opportunity for engagement, empowerment and hands on experience that will engage professional in Education to practically learn about how to use the emerging technologies in the $21^{\text {st }}$ Century classrooms. The ultimate aim of the Conference is that the knowledge and skills acquired during the conference will be a catalyst to improving teaching and learning in all educational establishments. It is also hoped that the knowledge disseminated during this conference will cause a sporadic desire all over the world to unlock the door of education using ICT and help to achieve the Millennium Goals in Education in Africa. It is also hoped that activities will greatly contribute to youth empowerment and engagement thereby reducing youth insurgence. All these efforts have gone a long way to reposition education in Africa and Nigeria in particular. It is therefore necessary to appreciate the contribution of these Associations to the development and provision of quality Education in Africa. This study will also be incomplete if the contributions of SITE (Society for Teacher and Technology Education) an umbrella body of AACE is not acknowledged. These Associations have also made immense contribution to the acquisition of pre-requisite skills, engagement and empowerment of young scholar's in the area of applications of modern technologies to teaching and learning in Africa. It is on record that the first SIG of the participants from Africa was inaugurated after the Tennessee Conference

\subsection{Relevant Literature}

Tishman (1995), futurist and technology specialist, explains why technology requires more teacher-student interaction than ever before, "Teachers need to show their students how to judge and evaluate the information they find". This is the reason for a learning strategy and activity that can help inculcate such skill and abilities in learners. Bruner (1973) said "It is not enough to merely gather information. If the individual is to understand it and learn from it, there is an essential, interpretive task." The need for inquiry-based learning and constructivist activities in the $21^{\text {st }}$ century school cannot therefore be over-emphasized. According to Erick and Reed (2002) 
Inquiry-based learning (IBL) is a classroom project oriented teaching approach based on constructivist and social constructivism theories of learning. Similarly, Howe and Strauss (2000) postulate that inquiry is a learning strategy that conceptualizes the idea of giving students the opportunity to create new knowledge from the available information given to them. Inquiry-based learning and constructivist activities are therefore essential in a time like this. They are effective tools the teacher needs in this contemporary time for preparing the nation builders and inculcating in their learners the skills and abilities needed for them to be key players in the global village (Bertram \& Lunsford, 2004). There is no time in the history of mankind when there is more access to information - useful and unuseful ones than now. Learners in modern society are being exposed to more information than they need hence, the need for them to acquire better skills on how to process this information. Web-Quest is probably one of the medium specially designed to achieve this by inculcating in the learners the ability to work with and sort out information. Expatiating on the importance of Web-Quest, Kamat and Shinde. (2009) say Web-Quest as an aspect of interactive multi-media inculcates in the learners skill and ability that helps them to work with information better in an information-driven age. It also equips them with the skills needed to function maximally and efficiently in the real world. Furthermore, Web-Quest activity is designed to promote student's ability to inquire and collaborate, as well as increase students' interest in learning, while participating in an Internet based unit. According to Muller, Elkund and Shaman (2006) combination of multi -media and inquiry and discovery approach that engages students' interest raise their critical abilities, focus their learning by providing subject matter of sufficient importance to help them build new mental patterns while discarding some old assumptions. Johnson and Johnson (1999) also argued against the lecture method, in a collaborated research study titled "Computer-mediated collaborative learning, an empirical evaluation" two cited the failure of lecture method to actively engage students. It was argued that lecture method relegates students to the role of passive spectators. Hence the two advocates for the use of technology enhanced instruction. There is little or no argument on whether learners think technology aids their learning, but the problem is if the learners know whether technology is good for them or not. In Nigeria, the need to effectively enhance the learning process and to ensure efficiency is urgent in the classroom teaching. Their argument is strongly in favour of using technology to facilitate instruction and augment the teacher's effort. Hammond and Berry (2000) are of the opinion that, the current emphasis is ensuring that technology is used effectively to create new opportunities for learning and to promote students achievements. Therefore, this study sets out to investigate the pre-service teachers' attitude to and the perceived benefits of using Web-Quests to aid their learning, skill acquisition, and the influence of gender, difference of age on the pre-service teachers' attitude and perceived benefits of using Web-Quest for teaching at the university level. Web-Quests are often cooperative in nature (Bayerbatch \& Burrel, 2001), requiring students to take on roles where they are part of a team that must accomplish the task (Dell, 2006). It is also useful in promoting higher-level thinking and to reduce truancy. (Carrol, Legg \& Taylor, 2003). The Web-Quest used in this study consisted six sections: introduction to tasks; process; resources; evaluation and conclusion and it was designed locally using the skills and knowledge based gained from SITE/AACE conferences and workshops. Based on the above the following objectives will addressed

\subsection{Research Objectives}

The following objectives are stated for this study: (i) examine students' attitude to the use Web-Quest in teaching and learning; (ii) determine the perceived benefits of Web-Quest to student's teachers, and (iii) investigate whether age has any influence on utilization of Web-Quest among the selected sample and find out if students' gender affects the perceived usefulness of Web-Quest.

\subsection{Research Questions}

The following question guides the study. (i) Do students' attitude affects their perceived usefulness? (ii) Is age a factor in the usage of Web-Quest among the selected sample? (iii) Does student sex have direct relationship with students' benefits?

\subsection{Research Hypotheses}

Hypothesis one: students attitude do not necessarily have significant influence on their perceived benefits of using Web-Quest.

Hypothesis two: student's gender does not have significant influence on students' perceived benefits of using Web-Quest for teaching TEE 304.

Hypothesis three: The age of the students do not necessarily affect their utilization of Web-Quest 


\section{Method}

\subsection{Research Design}

The descriptive or survey study research design was adopted for this study. It investigated the influence of age and gender on the attitude and perceived benefits of the pre-service teachers to the use of Web-Quests in teaching Philosophy of Education.

\subsection{Population and Sample}

The population for the study consisted of all the students teachers who registered for Education in the Faculty of Education, University of Ibadan .It was from this that a sample of 119 students were selected through purposive sampling techniques in the 300 level. These students were those that registered for the course. (TEE 304 during the 2009/2010 Session). The study samples were also stratified into gender, age and different groups based on their teaching subject. Part Three was purposively selected for the study because that was the session that the large course is being taking. A descriptive or survey research design was adopted for this study. The study samples were also given opportunity to use the Web-Quest and a group project to do using resources available on the Web-Quest (www.tee304webquest.edutechportal.ida.com.ng). The sample were distributed based on their subjects namely - English, Economics, Political Science, Geography, Kinetics and Health Education, Chemistry, Physics, Botany, Zoology, and Religious Studies making ten (10) groups in all.

\subsection{Instrument}

Two research instruments were used to collect data for the study. They were researcher designed questionnaire termed: TEE 304 WEBQUEST QUESTIONNAIRE and a Web-Quest designed by the researchers for the purpose of the study. Ninety six questionnaires were administered to the pre-service teachers, male and female altogether immediately after their TEE 304 examination. The questionnaire was designed using the four point Likert scale consisting of: Agree, Strongly agree, Disagree and strongly disagree. It is made up of two sections. Section A solicited for the bio data of the respondent, while section B was based on Student's Attitude to Web-Quest and for teaching TEE 304, student's perceived benefit of Web-Quest. The data collected was analyzed using Chi- Squares and t-test.

\subsection{Validation of the Instruments}

The initial drafted questionnaire was submitted to three experts in the field of Educational Technology and Tests and Measurement for content validity. It was vetted to ensure its appropriateness as well as the suitability to measure what it was designed to measure before the production of the final copy for the study. Based on constructive criticism and corrections identified, the questionnaire was reduced to 30 . Further test of reliability was conducted to test the reliability of the Instruments using Cronbach Alpha method (De-Vavs, 2000), the reliabilities of 0.67 and 0.78 were obtained for the two instruments

\section{Results and Discussions}

From the data analyzed, the following findings were discovered, it was discovered that age of the sample used had direct influence on their intention to use Web-Quest. The results also showed that the age of the students ranged between age categories 20-24yrs, 25-29yrs, 30-34yrs, >35yrs respectively. With each of the category having a chi-square value of 9.15, 21.62, 18.68 and 14.52 all of them were significant (See Table 1)

Table 1. Chi-square analysis of students' attitude to the use of Web-Quest according to age grades

\begin{tabular}{lllllllll}
\hline Age & $\begin{array}{l}\text { Strongly } \\
\text { Agreed }\end{array}$ & $\begin{array}{l}\text { Somewhat } \\
\text { Agreed }\end{array}$ & $\begin{array}{l}\text { Strongly } \\
\text { Disagreed }\end{array}$ & $\begin{array}{l}\text { Somewhat } \\
\text { Disagreed }\end{array}$ & Total & df & Chi-Square & P \\
\hline 15-19yrs & - & - & - & - & - & - & - & \\
$20-24 \mathrm{yrs}$ & 20 & 18 & 2 & 2 & 42 & 12 & 9.15 & 0.05 \\
& $(47.6 \%)$ & $(42.9 \%)$ & $(4.8 \%)$ & $(4.8 \%)$ & & & & \\
$25-29 \mathrm{yrs}$ & 18 & 20 & 2 & 1 & 41 & 12 & 21.62 & 0.05 \\
& $(42.9 \%)$ & $(45.6 \%)$ & $(4.8 \%)$ & $(2.4 \%)$ & & & & \\
$30-34 \mathrm{yrs}$ & 1 & 3 & & & 4 & 12 & 18.68 & 0.05 \\
& $(75 \%)$ & $(25 \%)$ & & & & & & \\
$35-39 \mathrm{yrs}$ & 2 & 1 & & & 3 & 12 & 14.52 & 0.05 \\
& $(66.7 \%)$ & $(33.3 \%)$ & & & & & & \\
\hline
\end{tabular}


In addition, the results showed that students exhibited positive desire to using Web-Quest. However, age difference accounted for the difference in their degree of interest and attitude to Web-Quest usage. Forty-five percent of the sample within the age 25-29 years had the highest chi-square value of 21.62 which implied that they had highest positive attitude towards Web-Quest than the others. The group also perceived Web-Quest to be more useful than other age categories. It was discovered that difference in age had varying level of influence on the perceived benefits of web- quest. This was so because the calculated chi-square of 17.64, 25.07, 9.75 and 12.37 were greater than the critical table value of 3.42 respectively, therefore the difference in age of the students had positive influence on their perceived benefit of Web-Quest (Table 2 refers). Students in the age category 25-29 years had more interest in using Web-Quest because of its benefits than other respondents in the other age category.

Table 2. Chi-square analysis of students' perceived benefit of Web-Quest according to age grades

\begin{tabular}{|c|c|c|c|c|c|c|c|c|}
\hline Age & $\begin{array}{l}\text { Strongly } \\
\text { Agreed }\end{array}$ & $\begin{array}{l}\text { Somewhat } \\
\text { Agreed }\end{array}$ & $\begin{array}{l}\text { Strongly } \\
\text { Disagreed }\end{array}$ & $\begin{array}{l}\text { Somewhat } \\
\text { Disagreed }\end{array}$ & Total & df & Chi-Square & $P$ \\
\hline \multicolumn{9}{|l|}{ 15-19yrs } \\
\hline $20-24 y r s$ & $\begin{array}{l}20 \\
(47.6 \%)\end{array}$ & $\begin{array}{l}15 \\
(35.7 \%)\end{array}$ & $\begin{array}{l}5 \\
(11.7 \%)\end{array}$ & $\begin{array}{l}2 \\
(4.8 \%)\end{array}$ & 42 & 12 & 17.64 & 0.05 \\
\hline $25-29 y r s$ & $\begin{array}{l}25 \\
(70 \%)\end{array}$ & $\begin{array}{l}10 \\
(24.4 \%)\end{array}$ & $\begin{array}{l}4 \\
(9.8 \%)\end{array}$ & $\begin{array}{l}2 \\
(4.9 \%)\end{array}$ & 41 & 12 & 25.07 & 0.05 \\
\hline $30-34 y r s$ & $\begin{array}{l}4 \\
(100 \%)\end{array}$ & $\begin{array}{l}0 \\
(0 \%)\end{array}$ & & & 4 & 12 & 9.76 & 0.05 \\
\hline $35-39 y r s$ & $\begin{array}{l}3 \\
(100 \%)\end{array}$ & $\begin{array}{l}0 \\
(0 \%)\end{array}$ & & & 3 & 12 & 12.37 & 0.05 \\
\hline
\end{tabular}

It was also discovered that gender had positive influence on the students' attitude and perceived benefits of Web-Quest. Female students showed more positive attitude to using Web-Quest than the male students .The obtained Chi-square value of 9.76 was greater than the table's chi-square value of 3.84 .Which implied that gender difference had a significant influence on students' attitude to using Web-Quest. In addition, $82.6 \%$ of the male respondents agreed to using Web-Quest for teaching TEE 304 as against $94 \%$ of the female respondents. This results revealed that the female students developed more inclination and likeness for Web-Quest than their male counterparts (See Table 3)

Table 3. Chi-square analysis of the influence of gender on the students' interest to use Web-Quest as medium of instruction

\begin{tabular}{lllllll}
\hline Gender & Interested & $\begin{array}{l}\text { Not } \\
\text { Interested }\end{array}$ & Total & $\begin{array}{l}\text { Chi-Square } \\
\text { Calculated }\end{array}$ & $\begin{array}{l}\text { Chi-Square } \\
\text { Critical }\end{array}$ & P \\
\hline Male & 38 & 8 & 46 & 9.76 & 3.84 & 0.05 \\
& $(82.6 \%)$ & $(17.4 \%)$ & & & & \\
Female & 47 & 13 & & & & \\
& $(94 \%)$ & $(6 \%)$ & & & & \\
\end{tabular}

The influence of gender is evident and this is reflected in the difference of the percentage of male who agreed that using Web-Quest will have positive impact on their learning and that of female respondents who also agreed that using Web-Quest had positive impact on their learning. 86.9\% of the female respondents agreed that using Web-Quest for teaching TEE 304 has the benefits indicated in the questionnaire, while only $82 \%$ of the male respondents agreed to Web-Quest having the listed benefits. This showed that the female respondents found Web-Quest more beneficial to their learning than the male respondents did. The female students have more positive attitude to and see more benefits in using Web-Quest for teaching them than the male students do. It was 
discovered that the difference in the teaching courses of the students do not have significant influence on their attitude to and perceived benefits of using Web-Quest for teaching them Philosophy of education [TEE 304]. They all considered Web-Quest useful in learning despite the variation in their fields or teaching courses. The variation in the field of study of the students does not have significant influence on the attitude and perception of the students to the use of Web-Quest for teaching philosophy of education [TEE 304]. This shows that using Web-Quest for teaching them philosophy of education does give all the student teachers, though having different teaching courses, equal chance of performance. They all have positive attitude to the use of Web-Quest as well positive perception to its benefits. Students from the Arts, Social Sciences and the Sciences all considered Web-Quest beneficiary and helpful to their learning. This showed that Web-Quest can be used creatively to teach all the subjects, ranging from arts, Social sciences, to the Sciences and the Humanities. Beach and Richard (2001) shared similar opinion in a related study on the use of inquiry based approach in Humanities.

\section{Conclusion}

The study has shown from its findings that Web-Quest is a pedagogical tool welcomed by the students, both male and female considered it useful, interesting and highly beneficial to their learning. This is not to mean, however, that some of the students didn't find it uninteresting, but the majority of the respondents did find the task delightful and interesting. Referring to the questionnaire, many of the students agreed that Web-Quest can really be a good tool useful for not just now but also in the future, and even in other courses apart from Philosophy of Education (TEE 304).As to their perceived benefits of Web-Quest, majority of the respondents see Web-Quest as a highly beneficial tool. They agreed and submitted that Web-Quest has a way of engaging their interest in learning, raising their critical thinking abilities, and helping them concentrate on their learning by making available relevant information at easy reach. It is believed by many of the respondents that Web-Quest fosters team spirit and positive collaboration in learning. It saves time and money, and helps fine tune their report writing skills. From this study, it is apparent that Web-Quest is an innovative and motivating tool that helped to promote high ordered thinking and student teachers learning. This finding is in line with Bellofatto et-al 2001, Benson and Bruce 2001), It is therefore the belief that if Nigeria as a country can fully embrace the philosophy of AACE, SITE and UNESCO to embrace technology enhanced learning and reposition its educational systems by providing quality education at all levels, the issue of insecurity and youth insurgence will be minimized to the barest minimum. This is so because the hither to unemployed youths will be gainful employed and would have been empowered with the necessary skills. Hence, provision of quality education to all with emphasis on skill acquisition, engagement and empowerment is seen as the only panacea to addressing the challenges of insecurity, terrorism and development. It is therefore, not out of place to appreciate the innumerable contributions of NAEMT, AACE, SITE, Carnegie Corporation of New York and UNESCO to repositioning and developing education in Africa and more importantly Nigeria. UNESCO and Carnegie are noted for financial assistance for the procurement/installation of modern technologies, training, staff development and collaboration. AACE (for the past 25years), SITE and NAEMT have provided the pedagogy, skills, different platforms termed Special Interest Group (SIG) and collaboration through international conferences to help achieve UN Declaration of education for sustainable development.

\section{References}

Beach, R., \& Myers, J. (2001). Inquiry-based English instruction: Engaging students in life and literature. New York: Teachers College Press.

Bellofatto, L., Bohl, N., Casey, M., Krill, M., \& Dodge, B. (2001). A rubric for evaluating Web Quest. Retrieved March 21, 2007, from http://webquest.sdsu.edu/webquestrubric.html

Benson, A., \& Bruce, B. (2001). Using the web to promote inquiry and collaboration: A snapshot of the inquiry page's development. Teaching Education, 12(2), 153-163. http://dx.doi.org/10.1080/10476210120068048

Beyerbach, B., \& Burrell, M. (2004). Preservice teachers response to a Webquest on culturally relevant teaching. Paper presented at the Society for Information Technology and Teacher Education International Conference 2004, Atlanta, GA.

Bishop, A. P., Bertram, B. C., \& Lunsford, K. J. (2004). Supporting Community Inquiry with Digital Resources. Journal of Digital Information, 5(3), 29-32.

Bruner, J. (1973). Going Beyond the Information Given. New York: Norton.

Callison, D. (1999). Key Words in Instruction: Inquiry. School Library Media Activities Monthly, 15(6), 38-42.

Carroll, V., Legg, R., \& Taylor, D. (2003). Redesigning an undergraduate Geography course at Trinity College Dublin using Web Quests. Paper presented at the World Conference on E-Learning in Corporate, 
Government, Healthcare, and Higher Education Phoenix, AZ.

De-Vavs, D. (2001). Research Design in Social Research. London: Sage Publishing.

Dell, E. (2006). Trainee teachers developing Web Quests as a form of assessment: An assessment tool for all seasons? Paper presented at the Society for Information Technology and Teacher Education International Conference 2006, Orlando.

Eick, C. J., \& Reed, C. J. (2002). What Makes an Inquiry Oriented Science Teacher? The Influence of Learning Histories on Student Teacher Role Identity and Practice. Science Teacher Education, 86, 401-416.

Gaskill, M., McNulty, A., \& Brooks, D. W. (2006). Learning from WebQuests. Journal of Science Education \& Technology, 15(2), 133-136. http://dx.doi.org/10.1007/s10956-006-9005-7

Howe, N., \& Strauss, W. (2000). Millennial rising: The next great generation. New York: Vintage Books.

Inquiry article found at the University of Illinois Library Resources Website. Retrieved from http://alexia.lis.uiuc.edu/ chip/inqdef.shtml

Johnson, D. W., \& Johnson, R. T. (1999). Learning together and alone: Cooperation, competition and individualization. Upper Saddle River, NJ: Prentice Hall.

Kamat, V., \& Shinde, J. (2009). Enrichment of the learning experience of rural children through interactive multimedia. The Pan-Commonwealth Forum on Open Learning.

Muller, D., Eklund, J., \& Sharman, M. (2006). The future of multimedia learning: Essential issues for research. MUL.

National Research Council. (2001). Inquiry; thoughts views, and strategies for the K-5 Classroom. NSF Division of elementary, secondary, and informational education. Retrieved from http://www.nsf.gov/pubs/2000/nsf99148/htmstart.htm

Rosenshine, B., Meister, C., \& Chapman, S. (1996). Teaching students to generate questions: A review of the intervention studies. Review of Educational Research, 66(2), 181-221. http://dx.doi.org/10.3102/00346543066002181

Sadker, D., \& Sadker, M. (1985). Is the classroom O.K.? Phi Delta Kappan.

Tishman, S., Perkins, N., \& Jay, E. (1995). The thinking classroom: Learning and teaching in a culture of thinking. Boston: Allen and Bacon.

UNESCO. (2001). General Assembly Resolution and Road map Towards the Implementation of the Millennium Development Declaration. 56th Sessions item 40 of the Provision of the Agenda and Follow-up and the outcome of the Millennium Development Summit, New York.

\section{Copyrights}

Copyright for this article is retained by the author(s), with first publication rights granted to the journal.

This is an open-access article distributed under the terms and conditions of the Creative Commons Attribution license (http://creativecommons.org/licenses/by/3.0/). 